\title{
Epidemije kuge u Banskoj Hrvatskoj i Slavoniji krajem 17. i početkom 18. stoljeća kao povod za početak organiziranja javnozdravstvenoga sustava
}

U brojnim valovima epidemije kuge koji su tijekom ranoga novog vijeka zahvaćali Habsburšku Monarhiju osobito su važne epidemije koje su harale u dugom razdoblju od 1677. do 1716. godine. Tada je kuga sporadično iz Ugarske, Štajerske, Srbije i Bosne prelazila i na prostore hrvatskih zemalja - Banske Hrvatske i Slavonije. Te su epidemije u dva navrata (1679. i 1713.) pogodile i Beč, glavni grad Monarhije. Istraživanje epidemija kuge 1677. - 1716. važno je za hrvatsku povijest jer je u to vrijeme započela sustavna organizacija protuepidemijske obrane na razini čitave Habsburške Monarhije. Upravo su epidemije kuge bile povod da se u Habsburškoj Monarhiji tada počne organizirati javnozdravstveni sustav.

Ključne riječi: kuga, epidemije, javno zdravstvo, Hrvatska, Slavonija, 17. i 18. stoljeće

\section{Uvod}

Ljudsku su vrstu epidemije napadale tijekom čitave povijesti. Jedna od najstrašnijih zaraznih bolesti u starom, srednjem i novom vijeku bila je kuga, koju uzrokuje bakterija Yersinia pestis. Zastrašujuće je kod kuge bilo to što se brzo širila na velikim područjima, a zajednice (gradovi, sela) u kojima se pojavila imale su vrlo visoke stope smrtnosti, ponekad iznad 50 \% ukupnoga broja stanovnika. Zbog nedovoljne razvijenosti medicinske znanosti liječnici su se stoljećima teško nosili s kugom. S vremenom su državne vlasti širom Europe počele primjenjivati stroge mjere izoliranja bolesnih od zdravih stanovnika, koje su pokazivale učinak jer su zaustavljale širenje epidemije. U tu svrhu mnogi su gradovi gradili karantenske 
građevine - lazarete ili kontumace (njem. Kontumaz) - kao trajne građevine, a u vrijeme epidemija prema zaraženim područjima organizirali su se privremeni sanitarni kordoni. ${ }^{1}$

Krajem 17. stoljeća Habsburška Monarhija još uvijek se protiv epidemija kuge borila privremenim mjerama. U slučaju izbijanja epidemije u gradovima su osnivana sanitarna povjerenstva koja su upravljala zbrinjavanjem bolesnih i nadzorom kontakata ljudi. S vremenom su bečke vlasti shvatile da se primjena karantene i sanitarnoga kordona može poboljšati stvaranjem organiziranoga sustava koji bi nastojao podizati učinkovitost tih mjera. Tijekom 30-ih godina 18. stoljeća taj će se sustav unaprijediti osnivanjem stalnoga Sanitarnoga kordona na granici s Osmanskim Carstvom. ${ }^{2} \mathrm{U}$ ovome radu obuhvatit će se razdoblje prijelaza iz 17. u 18. stoljeće, kada su habsburške vlasti napravile veliki korak prema organiziranju stalne protuepidemijske službe koja je prethodila osnivanju stalnoga Sanitarnoga kordona na granici prema Osmanskom Carstvu. Utvrdit će se koje su najvažnije institucionalne mjere u tome vremenu napravljene i koja je bila njihova važnost za Bansku Hrvatsku i Slavoniju.

\section{Velike epidemije kuge krajem 17. stoljeća}

U povijesti je posebno ostala zapamćena velika epidemija kuge koja je pogodila Beč 1679. godine. Ta je epidemija harala već 1675. - 1676. u Erdelju, a zatim 1677. i 1678. u Ugarskoj. ${ }^{3}$ Kada se početkom 1679. pojavila u Beču, dovela je do stravičnih gubitaka stanovništva. ${ }^{4}$ Procjene o broju umrlih Bečana od te epidemije vrlo su različite. Boris Velimirović i Helga Velimirović radili su procjene na temelju analiza prethodnih epidemija u Londonu i Baselu, u kojima je mortalitet iznosio između 10 i $23 \%$ ukupnoga stanovništva, te su zaključili da je kuga u Beču 1679. mogla odnijeti između 10000 i 25000 stanovnika od ukupno oko 110000 koliko ih je tada imao. ${ }^{5}$ Susanne Kühberger također donosi procjenu o oko $12000 \mathrm{umr}$ lih, tj. oko $10 \%$ ukupnoga stanovništva tadašnjega Beča. ${ }^{6}$ Među slične procjene

\footnotetext{
1 Lavoslav Gleisinger, Povijest medicine (Zagreb: Školska knjiga, 1978), 113.

2 O tome više u: Robert Skenderović, „Sanitarni kordon na Savi i začetci javnog zdravstva u Slavoniji”, u: Rijeka Sava u prošlosti. Zbornik radova znanstvenog skupa održanog u Slavonskom Brodu 18.-19. listopada 2013., ur. Branko Ostajmer (Slavonski Brod: Hrvatski institut za povijest, Podružnica za povijest Slavonije, Srijema i Baranje, 2015), 315-327.

3 Edward A. Eckert, „The Retreat of Plague from Central Europe, 1640-1720: A Geomedical Approach", Bulletin of the History of Medicine 74 (2000), br. 1: 15.
}

4 Franciscus Xav. Linzbauer, Codex sanitario-medicinalis Hungariae, tom I (Budae: Typis Caesareo-Regiae Scientiarum Universitatis, 1852), 276.

5 Boris Velimirovic, Helga Velimirovic, „Plague in Vienna”, Reviews of Infectious Diseases 11 (1989), br. 5: 819-820.

6 Susanne Kühberger, „Die Pest - 'Eine gefährlich-ansteckende Krankheit'. Die letzte Pestepidemie 1713 in Wien”, u: 300 Jahre Karl VI. 1711 - 1740. Spuren der Herrschaft des „letzten” Habsburgers, ur. Stefan Seitschek, Herbert Hutterer i Gerald Theimer (Beč: Österreichisches Staatsarchiv, 2011), 200. 
može se uvrstiti i ona Ulricha Knefelkampa, koji smatra da je umrlo između 8000 i 12000 ljudi. $^{7} \mathrm{Na}$ drugoj strani, prema Edwardu A. Eckertu u gradu je umrlo više od 60000 ljudi, odnosno oko polovice ukupnoga tadašnjeg stanovništva. ${ }^{8}$ Čak i kada bi se prihvatile procjene B. i H. Velimirović, S. Kühberger i U. Knefelkampa, može se reći da se radilo o velikoj tragediji. Međutim, doista je moguće da je postotak umrlih bio mnogo veći jer postoje primjeri u kojima su epidemije kuge ubijale više od polovice ukupnoga stanovništva. ${ }^{9}$ Velika tragedija iz 1679. ostavila je trajan trag na stanovnike Beča, pa i na samoga cara Leopolda, koji je nekoliko godina poslije u spomen na taj događaj dao u središtu grada izgraditi danas poznati zavjetni kužni pil (Pestsäule) posvećen Svetom Trojstvu.

Zapravo se radilo o epidemiji koja je u Habsburšku Monarhiju stigla iz Osmanskoga Carstva, u kojem je također žestoko harala. Slavonski franjevac fra Luka Ibrišimović javio je zagrebačkom biskupu Martinu Borkoviću već 1678. da je kuga harala po čitavom Osmanskom Carstvu te da se pojavila i u Budimu, a u Slavoniji u Cerniku. ${ }^{10}$ Od 1677. do 1680. kuga je harala po Bosni i Hercegovini. ${ }^{11}$ Postoje naznake da je 1680. opet došla u Slavoniju. Naime, fra Luka Ibrišimović piše biskupu Borkoviću u rujnu 1680. iz Koprivnice Iam pestis in diversis partibus istis auditur..., što je Radoslav Lopašić protumačio tako da je kuga te godine harala i u Slavoniji. ${ }^{12}$ Kuga se i sljedećih godina nastavila širiti Europom. U Pragu je izbila 1681., a u Njemačkoj je bila prisutna od 1680. do 1682. godine.

Kuga je dakle tih godina harala u njemačkim zemljama, Ugarskoj, Austriji, Češkoj, a unutar Osmanskoga Carstva u Srbiji, Bosni i Hercegovini i drugim zemljama Balkana. Ta je velika epidemija potvrdila obrazac širenja kuge iz Azije u Europu koji se stoljećima stalno ponavljao. Kuga je doista bila opasnost koja je stalno prijetila s istoka. U Habsburšku Monarhiju u pravilu je dolazila iz pravca Osmanskoga Carstva.

Ulrich Knefelkamp, „Das Verhalten von Ärzten in Zeiten der Pest (14. - 18. Jahrhundert)”, u: Der Mensch und seine Behandlung in der Medizin: Bloß ein Mittel zum Zweck? (Schriften des interdisziplinären Zentrums für Ethik an der Europa Universität Viadrina Frankfurt /Oder/), sv. 2, ur. Jan C. Joerden (Berlin; Heidelberg: Springer, 1998), 37.

8 Eckert, „The Retreat of Plague from Central Europe”, 17.

9 Godine 1739. Požegu u Slavoniji zahvatila je epidemija kuge. Matična knjiga umrlih sadržava poimenični popis 798 preminulih osoba, a grad je imao oko 1300 stanovnika, što znači da je u Požegi tada umrlo preko $60 \%$ stanovništva. Grad se brzo oporavio zbog doseljavanja, ali i brojnih vjenčanja udovaca i udovica. Samo nekoliko godina nakon toga Požega je ponovno imala oko 1300 stanovnika. O tome više u: Robert Skenderović, „Kuga u Požegi i Požeškoj kotlini 1739. godine”, Scrinia Slavonica 3 (2003): 157-170.

10 Radoslav Lopašić, „Slavonski spomenici za XVII. viek. Pisma iz Slavonije u XVII. vieku (1633. 1709.)", Starine JAZU XXX (1902): 51.

11 Rina Kralj-Brassard, „Grad i kuga: Dubrovnik 1691.”, Anali Dubrovnik 54/1 (2016): 123.

12 Lopašić, „Slavonski spomenici za XVII. viek”, 57. 
O tome koliko je taj val epidemije kuge pogodio Hrvatsku još uvijek se malo zna. Još je početkom 20. stoljeća Janko Barlè tvrdio da je Hrvatsku (Barlè piše „našu domovinu”) zahvatio tek 1682. godine..$^{13}$ Međutim, Ibrišimovićeva pisma iz 1678. i 1680. pokazuju da je tih godina kuga bila makar sporadično prisutna u Slavoniji. Vladimir Bazala, koji je 1962. sastavio Calendarium pestis za naše krajeve, znao je za Ibrišimovićevo pismo iz 1678., ali ništa nije spomenuo vezano uz 1680. godinu. ${ }^{14}$ Ipak, Lopašić je vjerojatno dobro interpretirao da je kuge bilo u Slavoniji i te godine.

Pisma fra Luke Ibrišimovića svakako su dokaz da je tih godina bilo kuge u Slavoniji. Na drugoj strani ni Banska Hrvatska nije ostala netaknuta. Gustav Piasek upućuje na povijesne izvore koji dokazuju da je kuga u Bansku Hrvatsku ušla iz pravca Štajerske i da je bila prisutna u Hrvatskom zagorju već 1679. godine. ${ }^{15}$ Kuga je 1678. bila u susjednoj Štajerskoj, u Ptuju i na vlastelinstvu Zavrč. Godine 1679. ušla je i u sam grad Varaždin, što je dovelo i do socijalnih nemira u vidu razbojstava.${ }^{16}$ Čini se da se 1680 . primirila, ali 1681. ponovno dolazi do Varaždina i Hrvatskoga zagorja iz pravca Štajerske. Piasek piše da su tada bila zahvaćena mjesta Vidovec, Ivanec, Križovljan i Gornja Voća te Zajezda i Hrašćina. ${ }^{17}$ Prema Piaseku, kuga je 1682. ponovno prodrla u grad Varaždin te navodi da mu je izvor za tu tvrdnju Historia Collegii Societatis Jesu in monte Graeco Zagrabiae siti. ${ }^{18}$ Epidemija se nastavila širiti, pa je iz Hrvatskoga zagorja prešla u Podravinu. Hrvoje Petrić piše da je zato Hrvatsko-slavonski sabor u studenom 1682. donio odredbe o stražama zbog širenja kuge koja se pojavila u okolici Koprivnice, dijelovima Križevačke krajine i u samim Križevcima. ${ }^{19}$ Dosadašnje fragmentirano znanje o toj epidemiji vidljivo je i iz činjenice da Bazala u Calendarium pestis ne govori ništa o kugi u Varaždinu i Hrvatskom zagorju 1679. - 1682., ali spominje da se 1682. kuga proširila na Zagreb, pa i na sam Gornji grad. Štoviše, o tome piše: „Tvrdilo se da su je na Kaptol donijeli franjevci koji su poslije žetve sakupljali po selima hranu i milostinju. U njihovu samostanu, na Kaptolu, oboljelo je nekoliko redovnika...”20 Povežu li se izvješća koja spominju Petrić, Piasek i Bazala, može se zaključiti da je 1679. - 1682. kuga harala čitavom središnjom Hrvatskom, ali se o broju žrtava ne zna ništa konkretno.

\footnotetext{
13 Janko Barlè, „Kuga u požeškoj okolini god. 1739.”, Liječnički vjesnik 28 (1906), br. 11: 386.

14 Vladimir Bazala, „Calendarium pestis (II)”, Acta historica medicinae, pharmaciae, veterinae 2 (1962), br. 2: 76.

${ }_{15}$ Gustav Piasek, „Neki podaci o kugi u Varaždinu i okolici od XVI. do XVIII. stoljeća”, Godišnjak Gradskog muzeja Varaždin 5 (1975), br. 5: 67-68.

16 Piasek, „Neki podaci o kugi u Varaždinu”, 69.

17 Piasek, „Neki podaci o kugi u Varaždinu”, 69.

18 Piasek, „Neki podaci o kugi u Varaždinu”, 70.

19 Hrvoje Petrić, „Mikroorganizmi, epidemije i liječenje bolesti u Varaždinskom generalatu”, Cris 14 (2012), br. 1: 310.
}

20 Bazala, „Calendarium pestis (II)”, 76. 
Godine 1683. kuga je nestala iz Njemačke i Habsburške Monarhije, pa i iz Banske Hrvatske, ali je ostala prisutna na Balkanu, uključujući i Bosanski pašaluk. ${ }^{21}$ Ponovno se na osmanskoj strani znatnije pojavila 1686. te je gotovo u kontinuitetu bila prisutna do 1694. godine. Tijekom 1691. kuga se iz toga pravca širi po Banovini (Petrinja, Sisak, Zrin, Kostajnica), Kordunu i Lici (u Plaški i Vrhovine). ${ }^{22}$ Tome valu epidemije bili su izloženi i gradovi širom Dalmacije. Godine 1691. izbila je epidemija kuge i u Dubrovniku. ${ }^{23}$

To je bilo vrijeme Velikoga bečkog rata 1683. - 1699., kada se linija bojišnice iz godine u godinu mijenjala. Carska habsburška vojska uspjela je od 1683. nizom pobjeda prodrijeti duboko na Balkan, pa je krajem 1680-ih stigla sve do Kosova i Makedonije. To je iz epidemiološke perspektive bilo vrlo opasno jer se radilo o prostoru na kojem je kuga već godinama harala. Ipak, očito su habsburške civilne i vojne institucije prilično uspješno vodile računa i o epidemiološkim mjerama jer se kuga tih godina nije uspjela znatnije proširiti na Habsburšku Monarhiju.

Poučeni godinama velikih stradavanja, Habsburgovci su 1690-ih intenzivirali organiziranje protuepidemijske službe. Najvažnije im je bilo samo središte Monarhije - Beč i Donja Austrija. Zbog toga je 14. listopada 1690. Leopold I. izdao Pest-Patent za Donju Austriju, koji je sadržavao odredbe protuepidemijskih mjera u slučaju izbijanja kuge u Ugarskoj i Hrvatskoj. ${ }^{24}$ Dana 28. listopada 1691. Leopold I. izdao je još jedan carski nalog o protuepidemijskim mjerama za grad Beč. ${ }^{25}$ Kuga je te godine ozbiljno prijetila Habsburškoj Monarhiji, što je nesumnjivo izravno utjecalo na careve poteze. Već 26. studenog iste godine Leopold I. izdao je još jedan carski nalog za Donju Austriju o protuepidemijskim mjerama jer je bilo potvrđeno da se kuga ponovno pojavila u Ugarskoj. ${ }^{26}$ Mjere su u tim carskim nalozima bile prije svega usmjerene na zatvaranje prometnica u slučaju epidemija i na to da se u Donju Austriju puštaju samo oni pojedinci iz Ugarske i Hrvatske koji su imali zdravstvenu potvrdu (glaubwürdige Fede) civilnih ili vojnih vlasti da su proveli određeno vrijeme u karanteni. Štoviše, u Pest-Patentu iz 1690. precizno piše da to znači da su na sigurnome mjestu proveli četiri tjedna u izolaciji. ${ }^{27}$ Mjere u Beču svodile su se na ograničavanje kretanja gradom i zatvaranje škola. Iz toga je vidljivo da su mjere 1690-ih uglavnom bile vezane uz ograničavanje slobode kretanja i karantenu, što je bilo u domeni civilnih i vojnih vlasti. Primjerice, u naredbi od 26. studenog 1691. izrijekom se naglašava da se

${ }^{21}$ Kralj-Brassard, „Grad i kuga: Dubrovnik 1691.”, 123.

22 Piasek, „Neki podaci o kugi u Varaždinu”, 71.

23 Kralj-Brassard, „Grad i kuga: Dubrovnik 1691.”, 123.

24 Linzbauer, Codex sanitario-medicinalis Hungariae, tom I, 335.

25 Linzbauer, Codex sanitario-medicinalis Hungariae, tom I, 337.

26 Linzbauer, Codex sanitario-medicinalis Hungariae, tom I, 338.

27 Linzbauer, Codex sanitario-medicinalis Hungariae, tom I, 336. 
zdravstvenu potvrdu može dobiti od lokalnih vlasti, gradonačelnika ili svećenika (von der Obrigkeit, Richter oder Pfarrer). ${ }^{28}$

Upravo u to vrijeme započele su važne promjene koje su dovele do stvaranja epidemiološke službe, ali i javnoga zdravstva. Još od kraja 16. stoljeća u Beču je djelovalo Sanitarno povjerenstvo (Collegium sanitatis, Sanitätskollegium), u kojem su sjedili predstavnici civilnih vlasti i jedan ili dva liječnika (Magister sanitatis). ${ }^{29} \mathrm{U}$ početku je djelovalo samo u vrijeme epidemija, a bečki Magister sanitatis imenovan je iz redova profesora tamošnjega Medicinskog fakulteta. Sanitarno povjerenstvo djelovalo je u Beču i imalo je važnu ulogu i tijekom epidemije 1679. godine, ali se neki današnji povjesničari vrlo kritički odnose prema njemu jer su u njemu glavnu riječ vodile uglavnom medicinski nekompetentne osobe, koje su kao takve loše djelovale u kriznoj epidemijskoj situaciji. ${ }^{30}$

\section{Novi val kuge od 1700. godine}

Bilo je to vrijeme razvoja apsolutističke habsburške države i njezinih institucija. Jedan od najboljih primjera oblikovanja tadašnjih državnih institucija može se pratiti upravo na području zdravstvene skrbi. Iskustva s prijašnjim epidemijama kuge navela su početkom 18. stoljeća habsburške vlasti na ideju da privremene „kužne” institucije i službe pretvore u stalne. Organiziranje stalnih službi zapravo je označavalo početak ustroja sustava javnoga zdravstva.

Godine 1700. kuga je ponovno krenula na pohod po Europi došavši na istočne granice Habsburške Monarhije - u okolicu Beograda i Temišvara. Zbog toga je Dvorsko ratno vijeće u Beču odmah naredilo da se prema granici s Osmanskim Carstvom uspostavi karantena te da se provedu mjere zaštite od širenja epidemije. ${ }^{31}$ Ipak, kuga je prešla na habsburšku stranu u Srijemu te se proširila u Irigu, Maradiku i okolnim naseljima. ${ }^{32}$ Iste godine 3. prosinca Hrvatska kraljevinska konferencija šalje dopis zamjeniku generala Slavonske krajine i poglavarstvima gradova Varaždina, Križevaca i Koprivnice da se zbog opasnosti od kuge zabranjuje svaka trgovina s Temišvarom i susjednim zemljama. ${ }^{33}$

Godine 1703. kuga se pojavila u Poljskoj i u njoj je harala punih deset godina, a proširila se i na okolne njemačke i baltičke zemlje. Godine 1707. opet je harala

28 Linzbauer, Codex sanitario-medicinalis Hungariae, tom I, 341.

29 Knefelkamp, „Das Verhalten von Ärzten in Zeiten der Pest”, 35.

30 Knefelkamp, „Das Verhalten von Ärzten in Zeiten der Pest”, 35.

31 Slavko Gavrilović, Srem od kraja XVII. do sredine XVIII. veka, Monografije, knjiga 12 (Novi Sad: Filozofski fakultet u Novom Sadu, Institut za istoriju, 1974), 239.

32 Gavrilović, Srem od kraja XVII. do sredine XVIII. veka, 239.

${ }_{33}$ Hrvatske kraljevinske konferencije, sv. I (1689. - 1716.), prir. Josip Barbarić et al. (Zagreb: Arhiv Hrvatske, 1985), 182. 
Bosnom i bila je prisutna i u Sarajevu. ${ }^{34}$ Poznato je da je iste godine kuge bilo i u Srbiji, pa i u samome Beogradu. ${ }^{35}$ Godine 1708 . osobito se snažno proširila po Ugarskoj. Istovremeno je nastavila prijetiti hrvatskim zemljama i iz pravca Osmanskoga Carstva. Dana 6. listopada 1708. o kugi u Sarajevu javile su unutarnjoaustrijske vlasti i komora iz Graza hrvatskom banu Ivanu Pálffyju te su tražile da prekine promet iz pravca Osmanskoga Carstva. ${ }^{36}$

Epidemija kuge koja se 1700. pojavila na granicama Habsburške Monarhije, a od 1708. prešla i na područje Ugarske, natjerala je habsburške vlasti na još veće aktiviranje protuepidemijskih mjera. U patentu od 20. studenog 1709. tadašnji car Josip I. upozorava sve civilne i crkvene vlasti Donje Austrije na epidemiju kuge koja se proširila po Ugarskoj te pojedinačno navodi brojna mjesta, među kojima i Kečkemet, „Racki grad” u Budimu, sav kraj između Dunava i Tise, Segedin i Arad, kraj oko rijeke Moriš te Erdelj. Zbog toga Josip I. zabranjuje promet s Ugarskom, a ulazak u Donju Austriju dopušta se samo onima koji imaju zdravstvenu potvrdu da su bili 40 dana u karanteni. ${ }^{37}$ Bila je to mjera koja se već primjenjivala tijekom epidemije 1690-ih. Međutim, u drugome patentu od 27. prosinca iste godine Josip I. napravio je novi korak u borbi protiv kuge. $U$ njemu je objavio da je odlučio radi zaštite od epidemije stvoriti tri linije obrane: prvu na podunavskom prostoru (na pravcu Ostrogon - Stolni Biograd - Vesprim - Simontornya - Pečuh - Siget - Šikloš - Osijek - Vukovar - Ilok - Petrovaradin), drugu na austro-ugarskoj i hrvatsko-ugarskoj granici (na pravcu Győr - St. Gotthard - Šopron - Čakovec - Legrad - Varaždin - Virovitica) i treću u okolici Beča (Hainburg - Prellenkirchen - Bruck - Mannersdorf - Ebenfurth Neustadt - Kirchschlag). ${ }^{38}$ Josip I. također je u tome patentu naredio da se uz te linije imaju sagraditi kontumaci (Contumaz- und deren Lazareth-Hauser) te da se za njih imaju osigurati liječnici. ${ }^{39}$ Josip I. u tom je patentu upotrijebio izraz „tri linije" (drey Linien), ali se može reći da se radilo zapravo o prvom pokušaju stvaranja sanitarnih kordona koji bi koncentrično bili raspoređeni prema Beču kao središtu Monarhije. Te tri linije obrane očito su izabrane iskustveno s obzirom na činjenicu da su epidemije u pravilu dolazile s istoka.

U pogledu organizacije državne protuepidemijske službe Erna Lesky ističe da se 1710. dogodio novi vrlo važan moment jer se te godine pojavljuje nova institucija, Hof-Commission in Sanitäts-Sachen - Dvorsko zdravstveno povjerenstvo (Sani-

\footnotetext{
${ }^{34}$ Janko Barlè, „Još nekoliko podataka o kugi god. 1739. i god. 1743.-1745.”, Liječnički vjesnik 34 (1912), br. 1: 6.

35 Gavrilović, Srem od kraja XVII. do sredine XVIII. veka, 240.

${ }^{36}$ Hrvatska (dalje: HR) - Arhiv Hrvatske akademije znanosti i umjetnosti, Zagreb (dalje: AHAZU)

- fond 8 - Obitelj Keglević, kut. III, 6. X. 1708.

37 Linzbauer, Codex sanitario-medicinalis Hungariae, tom I, 393.

38 Linzbauer, Codex sanitario-medicinalis Hungariae, tom I, 397.

39 Linzbauer, Codex sanitario-medicinalis Hungariae, tom I, 398.
} 
täts-Hofkommission).$^{40} \mathrm{Za}$ razumijevanje toga napretka u ustroju protuepidemijskih institucija važna je usporedba dvaju dokumenata. Početkom 1710. u Beču je napravljen dokument koji je sadržavao prijedloge mjera i lijekova za borbu protiv kuge koja je tada harala Ugarskom. Taj je dokument važan jer u njemu piše da su ga sastavili članovi Sanitarnoga povjerenstva Beča (Excelsum Consilium Sanitatis Viennae) na temelju izvješća Medicinskoga fakulteta u Beču i mnogih liječnika koji su se bavili epidemijom. ${ }^{41} \mathrm{U}$ tome dokumentu još se ne spominje Sanitäts-Hofkommission. Prema svemu sudeći, Sanitarno povjerenstvo Beča igralo je tada de facto i ulogu dvorskoga sanitarnog povjerenstva koje je savjetovalo vladara, a iz navedenoga dokumenta vidljivo je da je davalo preporuke i za druge habsburške zemlje. Međutim, već 14. kolovoza 1710. Josip I. objavio je carski dekret vezan uz epidemiju kuge u Ugarskoj, na kraju kojega stoji da je radi borbe protiv epidemije osnovao Dvorsko povjerenstvo (eine authorisirte Hof-Commission) za pitanja zaraze (in Contagions-Sachen), na čije je čelo imenovan Johann Christoph Frey- und Pannier-Herr von Oed, komorski i donjoaustrijski državni savjetnik. ${ }^{42}$

\section{Protuepidemijske mjere u Banskoj Hrvatskoj i Slavoniji 1709. - 1713. godine}

Vlasti su se u Banskoj Hrvatskoj i Slavoniji grčevito borile da se kuga ne proširi na naše prostore. Hrvatski je sabor tada kao i poslije tijekom 18. stoljeća kontrolirao zdravstvene prilike u Zagrebačkoj, Varaždinskoj i Križevačkoj županiji te Banskoj vojnoj krajini, a slavonska vojna i civilna vlast kontrolirala je zdravstvene prilike u Slavoniji i Srijemu. Važne su činjenice koje se mogu skupiti o tome kako su organizirali obranu od epidemije tih godina. Sustav kordona i karantena bio je sve učinkovitiji.

Prema zapisima Hrvatskoga sabora i Hrvatske kraljevinske konferencije, aktivna izgradnja obrambenoga sustava sanitarnih kordona i karantena započela je u Banskoj Hrvatskoj ujesen 1709. godine. Naime, početkom 1709. kuga se pojavila u Srijemskim Karlovcima, a zatim i u drugim srijemskim mjestima - Čereviću, Banoštoru i Remeti. ${ }^{43}$ Nesumnjivo je zbog tih događaja 5. listopada iste godine bečko Dvorsko ratno vijeće tražilo od Petra Keglevića da putnici koji ulaze iz Ugarske i Slavonije trebaju imati Passporten (putovnice odnosno propusnice) izdane od lokalnih zapovjednika. ${ }^{44}$ Kuga se doista proširila po čitavoj Ugarskoj i ozbiljno je prijetila Hrvatskoj. U svibnju 1709. bila je prisutna u Kečkemetu, a u

40 Erna Lesky, „Die österreichische Pestfront an der k. k. Militärgrenze”, Saeculum 8 (1957), br. 1: 86.

${ }^{41}$ Linzbauer, Codex sanitario-medicinalis Hungariae, tom I, 401.

42 Linzbauer, Codex sanitario-medicinalis Hungariae, tom I, 409.

${ }^{43}$ Gavrilović, Srem od kraja XVII. do sredine XVIII. veka, 240.

${ }^{44}$ HR-AHAZU-8, Obitelj Keglević, kut. III, 5. X. 1709. 
srpnju u segedinskom Palanku. ${ }^{45}$ Iste godine pojavila se i u budimskome predgrađu Tabanu. ${ }^{46}$

U rujnu 1709. Hrvatska kraljevinska konferencija donijela je odluku o zatvaranju prijelaza preko Drave kod Varaždina i u Drnju. O tim su mjerama obaviještene i vlasti u Štajerskoj i Kranjskoj te je predloženo da se u Varaždinu održi sastanak s predstavnicima Štajerske i Varaždinskoga generalata. ${ }^{47}$

Kako se povećavala opasnost od kuge, tako su se povećavale i mjere obrane. Nekoliko mjeseci poslije hrvatske su vlasti odlučile uspostaviti sustav obrane Banske Hrvatske od prodora epidemije na putnim pravcima iz smjera Slavonije. Hrvatski je sabor 16. prosinca 1709. odlučio da se odrede mjesta za karantenu i organizira protuepidemijska obrana prema Slavoniji (respectu partium inferiorum, seu Sclavoniae Inferioris) u Koprivnici i Križevcima. Pored toga određeno je da se prekine promet iz Međimurja preko Varaždina. ${ }^{48}$

Istovremeno su slavonske vojne i civilne vlasti gradile sustav protuepidemijske obrane prema Srbiji i Bosni. Kao dio toga sustava u Vukovaru je osnovana karantena za sve koji su dolazili s istoka iz zaraženih područja. ${ }^{49}$ Slavko Gavrilović ističe i da je za sve koji bi se samovoljno provukli kroz zaštitni sanitarni kordon iz zaraženoga na nezaraženo područje bila određena smrtna kazna. ${ }^{50}$

Početkom 1710. nastavljeno je zatvaranje Banske Hrvatske na svim prometnim pravcima sa sjevera (iz Ugarske) i istoka (iz Slavonije). Hrvatski sabor odlučio je 31. siječnja 1710. da se iz pravca Požege, Gradiške i Virovitice te na prometnim pravcima preko Varaždina, Križevaca i Jasenovca ne može ući u Bansku Hrvatsku bez propusnice lokalnih zapovjednika. Za kontrolu tih putnih pravaca određeni su predstavnici lokalne civilne i vojne vlasti: u Jasenovcu Nikola Jelačić kao zamjenik zapovjednika mjesta, u Varaždinu podžupani Franjo Kyss i Ivan Branjug, a u Križevcima sudac i magistrat grada. ${ }^{51}$

Kao što je rečeno, u ljeto 1710. car Josip I. osnovao je Dvorsko povjerenstvo za sanitarna pitanja (Hofkommission in Sanitätssachen) sa sjedištem u Beču. No u

\footnotetext{
${ }_{45}$ Slavko Gavrilović, Izvori o Srbima u Ugarskoj početkom XVIII. veka, knj. V, Zbornik za istoriju, jezik i književnost srpskog naroda, Odeljenje 2, Spomenici na tuđim jezicima, knj. 38 (Beograd: Srpska akademija nauka i umetnosti, 2005), 70.

${ }^{46}$ Slavko Gavrilović, Izvori o Srbima u Ugarskoj s kraja XVII. i početkom XVIII. veka, knj. III, Zbornik za istoriju, jezik i književnost srpskog naroda, Odeljenje 2, Spomenici na tuđim jezicima, knj. 36 (Beograd: Srpska akademija nauka i umetnosti, 2003), 278-279.

47 Hrvatske kraljevinske konferencije, sv. I, 298.

48 Zaključci Hrvatskog sabora, sv. II (1693. - 1713.), prir. Josip Buturac et al. (Zagreb: Državni arhiv NR Hrvatske u Zagrebu, 1958), 416.

${ }^{49}$ Gavrilović, Srem od kraja XVII. do sredine XVIII. veka, 241.

50 Gavrilović, Srem od kraja XVII. do sredine XVIII. veka, 241.

${ }^{51}$ Zaključci Hrvatskog sabora, sv. II, 429.
} 
hrvatskoj historiografiji nije posvećena pozornost činjenici da je u Grazu u isto vrijeme osnovana Hauptdeputation in Contagionssachen, a prema sačuvanoj arhivskoj građi bila je to važna institucija i za naše krajeve. Prema Walteru Brunneru, Deputaciju je osnovala unutarnjoaustrijska vlada. ${ }^{52} \mathrm{O}$ toj instituciji više podataka donosi Richard Peinlich, koji je napisao da je Deputacija u Grazu osnovana u lipnju 1710 . te da je djelovala do 1718 . godine. ${ }^{53}$ Doista, i u povijesnoj građi koja se čuva u hrvatskim arhivima od 1710. pojavljuju se dokumenti vezanu uz Deputaciju. Primjerice, spominje se već u jednom pismu Dvorskoga ratnog vijeća hrvatskom banu od 29. srpnja 1710. upravo kao in Contagions-Sachen angeordnete Deputation. ${ }^{54}$

Od 1710. Deputacija se javlja kao jedna od glavnih institucija koje su koordinirale protuepidemijske aktivnosti na jugoistoku Habsburške Monarhije. Uz nju je u tome glavnu riječ vodilo bečko Dvorsko ratno vijeće, a na nižoj razini surađivali su Hrvatski sabor i Hrvatska kraljevinska konferencija, Petar Keglević kao banski namjesnik te zapovjednici Hrvatsko-slavonske vojne krajine. Veći broj dopisa Deputacije iz Graza i Dvorskoga ratnog vijeća iz Beča Petru Kegleviću sačuvanih u hrvatskim arhivima dokazuje da je on bio glavni adresat s kojim su te institucije komunicirale u Banskoj Hrvatskoj.

Hrvatska kraljevinska konferencija 30. rujna 1710. ponovno ponavlja posvećenost tome da se zbog epidemije kuge drži pod kontrolom promet iz pravca Međimurja prema Varaždinu, a i promet iz Ugarske preko Drnja. Prijelaz iz Međimurja prema Varaždinu bio je pod banskom vlašću, a promet iz Ugarske kroz Drnje pod zapovjedništvom Varaždinske vojne granice (generalata). Stoga je Hrvatska kraljevinska konferencija svojem izaslaniku Adamu Oreškom tada naložila neka traži od Hanibala Heistera, zapovjednika Varaždinskoga generalata, da spriječi ilegalne prelaske iz Ugarske preko Drnja i Legrada, što su činili neki ljudi iz Vojne granice. ${ }^{55}$ Među zaključcima te konferencije od 30. rujna jest i odluka da se piše vlastima Donje Austrije, Kranjske i Koruške da u Banskoj Hrvatskoj stanovništvo nije zaraženo kugom. ${ }^{56}$ Vidljivo je iz tih izvora da se promet između zemalja Habsburške Monarhije u to vrijeme epidemije kuge nije potpuno obustavljao. Putovati su mogli ljudi koji su imali zdravstvene propusnice, tj. potvrde.

Car Josip I. objavio je 25. lipnja 1710. i Pest-Patent za Vojnu granicu. Taj je Pest-Patent važan jer zapravo znači početak ustroja protuepidemijske obrane kao druge

\footnotetext{
${ }_{52}$ Walter Brunner, „Pestkordon im Pölstal”, Zeitschrift des Historischen Vereines für Steiermark 82 (1991): 185.

53 Richard Peinlich, Geschichte der Pest in Steiermark, sv. II (Graz: Vereins-Buchdruckerei, 1878), 304 i 311 .

${ }^{54}$ HR - Hrvatski Državni arhiv, Zagreb (dalje: HDA) fond 9 - Konferencije Kraljevine Hrvatske, Dalmacije i Slavonije, kut. I, fol. 78.

55 Hrvatske kraljevinske konferencije, sv. I, 300.

56 Hrvatske kraljevinske konferencije, sv. I, 303.
} 
važne funkcije Vojne granice (pored one vojne). ${ }^{57}$ Bazala zato ističe da je Pest-Patent za Vojnu granicu od 25. lipnja „prvi propis koji govori o vladanju za vrijeme kuge u turskom pograničnom području” ${ }^{58} \mathrm{U}$ tome Pest-Patentu traži se da vojni zapovjednici u Petrovaradinu (za Slavonsku vojnu granicu) i Karlovcu (za Karlovački generalat) vode međusobnu komunikaciju i razmjenjuju informacije sa susjednim vojnim i civilnim sanitarnim povjerenstvima o širenju epidemije. Među člancima Pest-Patenta Vaniček je istaknuo i onaj u kojem se zapovjednicima Vojne granice naređuje da časnike i vojnike koji dolaze u Donju Austriju šalju putnim pravcima na kojima nema epidemije (eine pestfreie Reise-Route anzuweisen), što pokazuje da je i u tom slučaju primarni interes Dvora bio zaštititi Donju Austriju i glavni grad Beč. ${ }^{59}$ Tada se očito još nije razmišljalo o stalnom sanitarnom kordonu na granici prema Osmanskom Carstvu jer je kuga bila raširena po čitavoj Monarhiji.

Kuga je i dalje prijetila na samim granicama Banske Hrvatske. To je vidljivo i iz činjenice da je u studenome 1710. Hrvatska kraljevinska konferencija odlučila da se u Repašu organizira karantena za vojnike Varaždinskoga generalata koji su se zatekli u Ugarskoj i koji su ondje zaraženi kugom. ${ }^{60}$

Barlè tvrdi da se usprkos svim mjerama kuga 1710. pojavila i u samoj okolici Zagreba, u selima Rakovcu, Vrbovcu i Božjakovini: „Dne 9. prosinca 1710. pisao je karlovački general grof Josip Rabata zagrebačkom biskupu grofu Mirku Eszterházyu, da poduzme sve, kako se ne bi kuga dalje širila, jer je čuo od senjskog biskupa da kuga vlada u zagrebačkoj okolici. Saznao je i sâm da su sela Rakovac (Rakovec, op. R. S.), Vrbovac (Vrbovec, op. R. S.) pače Božjakovina okužena." ${ }^{61}$ Međutim, nije jasno je li se doista radilo o epidemiji ili samo o glasinama, koje su se tada također stalno širile i izazivale paniku. Štoviše, u siječnju 1711. Hrvatska kraljevinska konferencija šalje izvješće vlastima Donje Austrije, Štajerske i Koruške u kojem ih ponovno obavještava da u Banskoj Hrvatskoj nema kuge. ${ }^{62}$ Dakle, to izvješće izravno pobija informacije grofa Rabate.

Kuga je nastavila harati Ugarskom 1711. i 1712. godine: 1711. po Segedinu, Čongradu i Pešti, a 1712. ponovno je izbila u Tabanu (predgrađu Budima). ${ }^{63}$ Harala je i po Slavoniji. Slavonski komorski inspektor Alexander Johann von Kallaneck

\footnotetext{
${ }^{57}$ Franz Vaniček, Specialgeschichte der Militärgrenze aus Originalquellen und Quellenwerken geschöpft, sv. I (Beč: K. K. Hof- und Staatsdruckerei, 1875), 162.

58 Vladimir Bazala, „Dokumenti o zdravstvu u Vojnoj krajini, naročito o takozvanom kužnom kordonu", Acta historica medicinae, pharmaciae, veterinae 1 (1961), br. 2: 64.

59 Vaniček, Specialgeschichte der Militärgrenze, sv. I, 163.

${ }^{60}$ Hrvatske kraljevinske konferencije, sv. I, 301.

${ }^{61}$ Barlè, „Još nekoliko podataka o kugi”, 6.

62 Hrvatske kraljevinske konferencije, sv. I, 303.

${ }^{63}$ Gavrilović, Izvori o Srbima u Ugarskoj s kraja XVII. i početkom XVIII. veka, knj. III, 324; Gavrilović, Izvori o Srbima u Ugarskoj početkom XVIII. veka, knj. V, 79.
} 
javio je 18. studenog 1711. bečkim vlastima da se kuga po treći put od Mira u Srijemskim Karlovcima ponovno pojavila u Slavoniji te da su od nje umrle „mnoge stotine" ljudi. ${ }^{64}$

Tijekom 1711. i 1712. može se pratiti stalna komunikacija između vlasti Banske Hrvatske i susjednih habsburških zemalja. Banska Hrvatska i dalje je držala zatvorene prijelaze preko Drave, o čemu je 12. siječnja 1712. Hrvatska kraljevinska konferencija obavijestila Ugarsku dvorsku kancelariju. ${ }^{65}$

Vidljivo je da je Banska Hrvatska 1712. nastavila s organiziranom borbom protiv epidemije. Kao mjere obrane od kuge Hrvatska kraljevinska konferencija odredila je na sjednici 16. veljače 1712. osnivanje karantenskih mjesta (ut...locus eiusmodi quarantanae constituatur) u Koprivnici, Križevcima, Varaždinu i Zagrebu. ${ }^{66} \mathrm{U}$ ožujku 1712. Hrvatska kraljevinska konferencija donosi odluku o osnivanju karantene u Križevcima i Ludbregu ${ }^{67}$ Razloga za daljnje jačanje mjera je bilo jer je iste godine slavonski inspektor Kallaneck javio da se u naseljima između Đurđevca i Koprivnice pojavila kuga, pa su zatvoreni svi putovi iz Slavonije prema Varaždinskom generalatu. ${ }^{68} \mathrm{O}$ pojavi kuge između Đurđevca i Koprivnice saznala je i Deputacija u Grazu te je 7. siječnja 1712. pisala Petru Kegleviću da potvrdi je li istina da se ona pojavila u Virju. ${ }^{69}$ Ubrzo nakon toga, 26. veljače 1712., Deputacija ponovno piše Petru Kegleviću te ga, zbog vijesti da se između Đurđevca i Koprivnice pojavila kuga, traži da se putne propusnice izdaju samo za ona mjesta u kojima 40 dana nije bilo nijednoga slučaja kuge. ${ }^{70}$ Vjekoslav Klaić piše da je vijest o kugi u Varaždinskoj krajini došla i do Beča. U Beču se tada zatekao grof Ivan Drašković, koji je o tome 24. veljače 1712. pisao zagrebačkom biskupu Eszterházyju. ${ }^{71}$ Kuga je očito te godine bila prisutna u Slavoniji jer Barlè navodi podatak da je u spomenici župe Stražeman kod Požege zapisano da je 1712. epidemija zahvatila selo Orljavac, koje je pripadalo toj župi. ${ }^{72}$

Vidljivo je da su civilne i vojne vlasti u Hrvatskoj i Slavoniji ulagale velike napore u borbu protiv epidemije, a mjere su očito davale rezultate. Premda je epidemija došla do samih granica Kraljevine, Hrvatska kraljevinska konferencija u rujnu 1712. šalje obavijest Ugarskoj dvorskoj kancelariji da u Banskoj Hrvatskoj još

\footnotetext{
${ }^{64}$ Gavrilović, Srem od kraja XVII. do sredine XVIII. veka, 241.

${ }^{65}$ Hrvatske kraljevinske konferencije, sv. I, 302.

${ }^{66}$ Hrvatske kraljevinske konferencije, sv. I, 316.

${ }^{67}$ Hrvatske kraljevinske konferencije, sv. I, 319.

68 Gavrilović, Srem od kraja XVII. do sredine XVIII. veka, 241.

${ }^{69}$ HR-AHAZU-8, Obitelj Keglević, kut. V, 7. I. 1712.

70 HR-AHAZU-8, Obitelj Keglević, kut. V, 26. II. 1712.

71 Vjekoslav Klaić, „Hrvatska pragmatička sankcija”, Rad JAZU 206 (1915): 72.

72 Barlè, „Još nekoliko podataka o kugi”, 6.
} 
uvijek nema kuge. ${ }^{73}$ Deputacija iz Graza 17. prosinca 1712. još se jednom obratila Petru Kegleviću, upozoravajući ga na opasnost od širenja kuge iz pravca Ugarske jer se pojavila i u okolici Sigeta. Stoga je od Keglevića tražila neka se poduzmu mjere da se kuga ne proširi na Bansku Hrvatsku. ${ }^{74}$

Epidemija je prijetila Banskoj Hrvatskoj i 1713., i to iz pravca Štajerske, Austrije i Ugarske. U siječnju 1713. Deputacija je bila nezadovoljna ozbilinošću provedbe protuepidemijskih mjera u Banskoj Hrvatskoj te je od Petra Keglevića tražila da se one postrože. ${ }^{75}$ Dana 24. kolovoza 1713. Deputacija je tražila od Keglevića neka u Štajersku pošalje dva liječnika i četiri ranarnika radi suzbijanja kuge, što pokazuje koliko je teška situacija tada bila i u Austriji. ${ }^{76}$ Štoviše, te je godine epidemija kuge ponovno zahvatila Beč, u kojem je tada umrlo oko 9000 ljudi. ${ }^{77}$ To je ujedno bilo poražavajuće za bečki dvor, koji je, kao što je pokazano, godinama činio sve moguće da epidemija ne zahvati i samo središte Monarhije. Prijetnja epidemije natjerala je vlasti Banske Hrvatske da se još više potrude u organiziranju protuepidemijske obrane. Doista, nastavljene su mjere zatvaranja Banske Hrvatske prema zaraženim područjima - u prvom redu kontrola putnika na važnim putnim pravcima. Hrvatsko kraljevinsko vijeće zato je u kolovozu iste godine odredilo osobe odgovorne za kontrolu putnih pravaca, odnosno ulaska u Bansku Hrvatsku iz smjera Štajerske, Austrije i Ugarske: Nikolu Dudića na posjedima Trakošćan i Klenovnik, Baltazara Magdalenića u Krapini, Adama Bedekovića u Taboru, Matiju Marića i Grgura Vrančića na prijelazima Zavrč i Ormož, Grgura Czindeya u Varaždinu te Stjepana Keczera na prijelazima kod Ludbrega, Đelekovca i Torčeca. ${ }^{78}$ Ipak, neodgovornost pojedinaca bila je sveprisutna, a ponekad su ju pokazivali i neki od vodećih ljudi Banske Hrvatske. Tako je u rujnu 1713. Deputacija pisala Kegleviću da je prema izvješću povjerenika Franza Xavera Quallandra pri prijelazu kod Sauritcha (danas Zavrč u Sloveniji) grof Ivan Drašković prekršio sanitarne propise, a sve su takve situacije bile rizične. ${ }^{79}$

Prigovori Deputacije iz Graza pokazuju da je bilo problema u održavanju protuepidemijskih mjera u Banskoj Hrvatskoj. Svaki propust mogao je dovesti do širenja epidemije. Doista, Barlè je pisao da je naše krajeve kuga zahvatila i 1713. godine.$^{80}$ Ipak, poznati izvori ne potvrđuju njegove tvrdnje. Vrlo je moguće da se kuga sporadično pojavljivala u Slavoniji i Srijemu. Međutim, u Banskoj Hrvatskoj

\footnotetext{
${ }^{73}$ Hrvatske kraljevinske konferencije, sv. I, 323.

${ }^{74}$ HR-AHAZU-8, Obitelj Keglević, kut. V, 17. XII. 1712.

75 HR-AHAZU-8, Obitelj Keglević, kut. V, 16. I. 1713.

76 HR-AHAZU-8, Obitelj Keglević, kut. V, 24. VIII. 1713.

77 Linzbauer, Codex sanitario-medicinalis Hungariae, tom I, 403.

78 Hrvatske kraljevinske konferencije, sv. I, 338.

79 HR-AHAZU-8, Obitelj Keglević, kut. V, 9. IX. 1713.

80 Barlè, „Kuga u požeškoj okolini god. 1739.”, 386.
} 
nije bila prisutna, pa se može zaključiti da su protuepidemijske mjere od 1708 . do 1713. spasile središnju Hrvatsku od te pošasti. Epidemija se širom Monarhije uglavnom smirila krajem 1713. godine. Na temelju vijesti da se u susjednim zemljama epidemija smirila, Hrvatska kraljevinska konferencija javila je u siječnju 1714. povjerenicima na granicama Banske Hrvatske da se promet može opet slobodno odvijati. ${ }^{81} \mathrm{U}$ nekim je susjednim zemljama kuga ipak ostala prisutna. Tako je u samoj Štajerskoj sporadično izbijala sve do kraja 1716. godine. ${ }^{82}$ Ukupno gledajući, Štajerci su u valu od 1710. do 1716. imali sedam godina epidemije. Što se tiče hrvatsko-slavonskoga prostora, u Slavoniji je bilo sporadičnih slučajeva, kao i u Varaždinskom generalatu, a Banska Hrvatska prošla je nezaražena. ${ }^{83}$

\section{Liječnici Kraljevine}

U to vrijeme u Slavoniji nema spomena o djelovanju školovanih doktora medicine. Iz kasnijih desetljeća poznato je da su se liječenjem bolesnika i pripravom lijekova bavili franjevci i isusovci, a u gradovima su obično djelovali ranarnici (njem. Feldtscherer), osobito u onima sa stalnim vojnim postrojbama (u Osijeku i Brodu na Savi). Stoga se može pretpostaviti da je takva situacija bila i u prvim desetljećima 18. stoljeća ${ }^{84}$ Povijesni izvori o tome gotovo i nisu poznati. Jedino se zna da je u Brodu na Savi 1712. živjela Maria Theresia Terfisin, felcarin, kako je upisana u matičnoj knjizi krštenih. Radilo se očito o supruzi nekoga "felčera” Terfisina koji je tada živio u Brodu na Savi. ${ }^{85}$

Na drugoj strani, početkom 18. stoljeća Banska Hrvatska plaćala je tri do četiri doktora medicine koji su djelovali kao liječnici Kraljevine. Prema zapisima Hrvatskoga sabora i Hrvatske kraljevinske konferencije moglo bi se zaključiti da je namjera bila imati po dva doktora medicine u Zagrebu i Varaždinu. Poznato je iz toga vremena da je u Varaždinu od 1691. do svoje smrti 1706. kao liječnik Kraljevine djelovao dr. med. Ivan Gotfrid Karlek. ${ }^{86}$ Karleka je nakon smrti zamijenio dr. med. Ivan Leopold Payer. ${ }^{87}$ Zna se i da je od 1696. do 1704. u Zagrebu kao

\footnotetext{
${ }^{81}$ Hrvatske kraljevinske konferencije, sv. I, 348.

82 Peinlich, Geschichte der Pest in Steiermark, 277.

83 Peinlich, Geschichte der Pest in Steiermark, 287.

84 Robert Skenderović, „Zdravstvene reforme Marije Terezije u slavonskom Provincijalu i Generale Normativum Sanitatis (1770.)", Scrinia Slavonica 5 (2005): 118.

85 Robert Skenderović, Najstarija matična knjiga brodske župe Presvetog Trojstva (1701. - 1735.) (Slavonski Brod: Hrvatski institut za povijest, Podružnica za povijest Slavonije, Srijema i Baranje, 2012), 186.

86 Rudolf Horvat, „Hrvatski državni liječnici u XVII. vijeku”, Liječnički vjesnik 53 (1931), br. 4: 362; Zaključci Hrvatskog sabora, sv. II, 59 i 326.

87 O Payeru više u: Snježana Paušek-Baždar, „Ivan Leopold Payer i recepcija Paracelsusovih gledišta u Hrvatskoj", Prilozi za istraživanje hrvatske filozofske baštine 35 (2009), br. 1-2 (69-70): 55-68.
} 
liječnik Kraljevine djelovao dr. med. Johann Baptista Fliszer. ${ }^{88}$ Zapisnici Hrvatskoga sabora i Hrvatske kraljevinske konferencije donose važne podatke i za kasnija imenovanja. Iz zaključaka Hrvatske kraljevinske konferencije od 26. ožujka 1708. vidi se da je za liječnika Kraljevine (Medicus Regni) izabran dr. med. Rupert Slizovy. Međutim, o njemu ni Sabor ni Kraljevinske konferencije poslije više ništa ne donose, pa se o njegovu djelovanju ništa ne zna. ${ }^{89}$ Vezano uz vrijeme epidemije treba ovdje spomenuti još dva imena. Između 1706. i 1710. među liječnicima Kraljevine spominje se i Gašpar Carusi (1710. kao Medicus Varasdiensi Karusa) ${ }^{90}$ Zadnji među navedenima, 20. listopada 1710. među liječnike Kraljevine primljen je i Eisenschmidt (Aizensmitt, nije poznato ime), koji je imao dužnost stanovati i raditi u Zagrebu. ${ }^{91}$

Hrvatska kraljevinska konferencija namjeravala je zaposliti još jednoga liječnika (ut procuret Magistrum sanitatis), te se zbog toga 20. studenog 1710. obratila zagrebačkom liječniku Eisenschmidtu. ${ }^{92}$ Kako je vidljivo iz popisa izdataka Kraljevine 1710., na plaći se kao službenici Kraljevine spominju tri liječnika: varaždinski liječnici Carusi (plaća 400 rajnskih forinti) i Payer (plaća 300 rajnskih forinti) te liječnik Eisenschmidt (plaća 300 rajnskih forinti). ${ }^{93}$ Posebno je zanimljivo u tom popisu da je među izdatke uvrštena i plaća tada ispražnjenoga mjesta drugoga zagrebačkog liječnika - u izvoru piše Medicus Zagrabiensi, s plaćom od 400 rajnskih forinti. Vidljivo je da su postojale i razlike u plaći među njima, koje je Rudolf Horvat objašnjavao razlikom u iskustvu liječnika, pa su mlađi imali manju plaću, a stariji i iskusniji veću. ${ }^{94}$ No moguće je da se radilo i o različitim radnim mjestima - da je Banska Hrvatska plaćala dvojicu liječnika kao liječnike Kraljevine (Medicus Regni), a dvojicu kao gradske liječnike (Magister sanitatis).

Činjenica da su tada plaćana četiri doktora medicine pokazuje da je Banska Hrvatska u vrijeme epidemije 1690 -ih i početkom 18. stoljeća već imala stručne liječnike koji su mogli djelovati u skladu s ondašnjim medicinskim znanjem. Naravno, u odnosu na prostor na kojem su djelovali i na broj stanovnika, bilo ih je izrazito malo.

\footnotetext{
${ }^{88}$ Zaključci Hrvatskog sabora, sv. II, 82; Horvat, „Hrvatski državni liječnici u XVII. vijeku”, 365.

${ }^{89}$ Hrvatske kraljevinske konferencije, sv. I, 241.

90 Zaključci Hrvatskog sabora, sv. II, 326 i 447.

${ }_{91}$ Zaključci Hrvatskog sabora, sv. II, 436.

${ }_{92}$ Hrvatske kraljevinske konferencije, sv. I, 302.

93 Zaključci Hrvatskog sabora, sv. II, 447.

94 Horvat, „Hrvatski državni liječnici u XVII. vijeku”, 365.
} 


\section{Zaključak}

Epidemije kuge koje su harale Habsburškom Monarhijom od 1677. do 1716. snažno su utjecale na razvoj zdravstvenih institucija i organiziranje javnoga zdravstva. Pokazale su da je potrebno zapošljavanje većega broja školovanih doktora medicine te osnivanje institucija koje će se baviti zdravstveno-epidemiološkim pitanjima, osobito u vrijeme samih epidemija. Godine 1710. tadašnji je car Josip I. osnovao Dvorsko sanitarno povjerenstvo (Sanitäts-Hofkommission), koje će uskoro postati središnja javnozdravstvena institucija Habsburške Monarhije. Istraživanje povijesne građe pokazuje da su za hrvatsko-slavonski prostor u vrijeme epidemije 1708. - 1716. posebno važne ipak bile druge dvije institucije - bečko Dvorsko ratno vijeće, a od 1710. i Deputacija (Hauptdeputation in Contagionssachen) iz Graza. Iz navedenih dokumenata vidljivo je da je Deputacija kao unutarnjoaustrijska glavna (Haupt-) protuepidemijska institucija u velikoj mjeri koordinirala i protuepidemijske aktivnosti na području Banske Hrvatske i Varaždinskoga generalata. Deputacija i Dvorsko ratno vijeće komunicirali su na nižoj razini ponajviše s Petrom Keglevićem kao banskim namjesnikom, a on je svoje aktivnosti koordinirao s Hrvatskim saborom i Hrvatskim kraljevinskim konferencijama. Stoga se upravo u ostavštini Petra Keglevića može naći najviše dokumenata o protuepidemijskim mjerama u to vrijeme. Deputacija iz Graza raspuštena je 1718., ali je Dvorsko sanitarno povjerenstvo nastavilo djelovati nakon završetka epidemije kao stalna institucija. Epidemija kuge koja je u Habsburškoj Monarhiji trajala od 1708. do 1716. u tom je smislu vrlo važna jer su iskustvo i ustroj protuepidemijskoga sustava izgrađenog u to vrijeme bili temelj za uspostavu kasnijega stalnog sustava sanitarnih povjerenstava i Sanitarnoga kordona, koji je započeo 1730-ih, a potpuno je oblikovan donošenjem Općega zdravstvenog zakona (Generale normativum in re sanitatis) 1770. godine. Iskustva su se posebice pokazala korisnima za Bansku Hrvatsku, koju epidemija kuge 1708. - 1716. zahvaljujući protuepidemijskim mjerama nije zahvatila. 


\section{Neobjavljeni izvori}

Hrvatska - Arhiv Hrvatske akademije znanosti i umjetnosti, Zagreb - fond 8 Obitelj Keglević (HR-AHAZU-8).

Hrvatska - Hrvatski državni arhiv, Zagreb - fond 9 - Konferencije Kraljevine Hrvatske, Dalmacije i Slavonije (HR-HDA-9).

\section{Objavljeni izvori i literatura}

Barlè, Janko. „Još nekoliko podataka o kugi god. 1739. i god. 1743.-1745.” Liječnički vjesnik 34 (1912), br. 1: 6-12.

Barlè, Janko. „Kuga u Požeškoj okolini god. 1739.” Liječnički vjesnik 28 (1906), br. 11: 386-387.

Bazala, Vladimir. „Dokumenti o zdravstvu u Vojnoj krajini, naročito o takozvanom kužnom kordonu". Acta historica medicinae, pharmaciae, veterinae 1 (1961), br. 2: 64-81.

Bazala, Vladimir. „Calendarium pestis (II)”. Acta historica medicinae, pharmaciae, veterinae 2 (1962), br. 2: 72-87.

Brunner, Walter. „Pestkordon im Pölstal”. Zeitschrift des Historischen Vereines für Steiermark 82 (1991): 185-193.

Eckert, Edward A. „The Retreat of Plague from Central Europe, 1640-1720: A Geomedical Approach". Bulletin of the History of Medicine 74 (2000), br. 1: 1-28.

Gavrilović, Slavko. Izvori o Srbima u Ugarskoj s kraja XVII. i početkom XVIII. veka, knjiga III. Zbornik za istoriju, jezik i književnost srpskog naroda, Odeljenje 2, Spomenici na tuđim jezicima, knjiga 36. Beograd: Srpska akademija nauka i umetnosti, 2003.

Gavrilović, Slavko. Izvori o Srbima u Ugarskoj početkom XVIII. veka, knjiga V. Zbornik za istoriju, jezik i književnost srpskog naroda, Odeljenje 2, Spomenici na tuđim jezicima, knjiga 38. Beograd: Srpska akademija nauka i umetnosti, 2005.

Gavrilović, Slavko. Srem od kraja XVII. do sredine XVIII. veka. Monografije, knjiga 12. Novi Sad: Filozofski fakultet u Novom Sadu, Institut za istoriju, 1974.

Gleisinger, Lavoslav. Povijest medicine. Zagreb: Školska knjiga, 1978.

Horvat, Rudolf. „Hrvatski državni liječnici u XVII. vijeku”. Liječnički vjesnik 53 (1931), br. 4: 352-370.

Hrvatske kraljevinske konferencije, svezak I (1689. - 1716.), priredili Josip Barbarić, Josip Kolanović, Andrija Lukinović i Vesna Šojat. Zagreb: Arhiv Hrvatske, 1985. 
Klaić, Vjekoslav. „Hrvatska pragmatička sankcija”. Rad JAZU 206 (1915): 62-135. Knefelkamp, Ulrich. „Das Verhalten von Ärzten in Zeiten der Pest (14. - 18. Jahrhundert)". U: Der Mensch und seine Behandlung in der Medizin: Bloß ein Mittel zum Zweck? (Schriften des interdisziplinären Zentrums für Ethik an der Europa Universität Viadrina Frankfurt /Oder/), svezak 2, uredio Jan C. Joerden, 13-40. Berlin; Heidelberg: Springer, 1998.

Kralj-Brassard, Rina. „Grad i kuga: Dubrovnik 1691. godine”. Anali Dubrovnik 54/1 (2016): 115-170.

Kühberger, Susanne. „Die Pest - 'Eine gefährlich-ansteckende Krankheit'. Die letzte Pestepidemie 1713 in Wien”. U: 300 Jahre Karl VI. 1711 - 1740. Spuren der Herrschaft des "letzten” Habsburgers, uredili Stefan Seitschek, Herbert Hutterer i Gerald Theimer, 200-202. Beč: Österreichisches Staatsarchiv, 2011.

Lesky, Erna. „Die österreichische Pestfront an der k. k. Militärgrenze”. Saeculum 8 (1957), br. 1: 82-106.

Linzbauer, Franciscus Xav. Codex sanitario-medicinalis Hungariae, tom I. Budae: Typis Caesareo-Regiae Scientiarum Universitatis, 1852.

Lopašić, Radoslav. „Slavonski spomenici za XVII. viek. Pisma iz Slavonije u XVII. vieku (1633. - 1709.)". Starine JAZU XXX (1902): 1-176.

Paušek-Baždar, Snježana. „Ivan Leopold Payer i recepcija Paracelsusovih gledišta u Hrvatskoj”. Prilozi za istraživanje hrvatske filozofske baštine 35 (2009), br. 1-2 (69-70): 55-68.

Peinlich, Richard. Geschichte der Pest in Steiermark, svezak II. Graz: Vereins-Buchdruckerei, 1878.

Petrić, Hrvoje. „Mikroorganizmi, epidemije i liječenje bolesti u Varaždinskom generalatu". Cris 14 (2012), br. 1: 306-319.

Piasek, Gustav. „Neki podaci o kugi u Varaždinu i okolici od XVI. do XVIII. stoljeća”. Godišnjak Gradskog muzeja Varaždin 5 (1975), br. 5: 67-75.

Skenderović, Robert. „Kuga u Požegi i Požeškoj kotlini 1739. godine”. Scrinia Slavonica 3 (2003): 157-170.

Skenderović, Robert. Najstarija matična knjiga brodske župe Presvetog Trojstva (1701. - 1735.). Slavonski Brod: Hrvatski institut za povijest, Podružnica za povijest Slavonije, Srijema i Baranje, 2012.

Skenderović, Robert. „Sanitarni kordon na Savi i začetci javnog zdravstva u Slavoniji”. U: Rijeka Sava u prošlosti. Zbornik radova znanstvenog skupa održanog u Slavonskom Brodu 18.-19. listopada 2013., uredio Branko Ostajmer, 315-327. Slavonski Brod: Hrvatski institut za povijest, Podružnica za povijest Slavonije, Srijema i Baranje, 2015. 
Skenderović, Robert. „Zdravstvene reforme Marije Terezije u slavonskom Provincijalu i Generale Normativum Sanitatis (1770.)”. Scrinia Slavonica 5 (2005): 115-143.

Vaniček, Franz. Specialgeschichte der Militärgrenze aus Originalquellen und Quellenwerken geschöpft, svezak I. Beč: K. K. Hof- und Staatsdruckerei, 1875.

Velimirovic, Boris; Velimirovic, Helga. „Plague in Vienna”. Reviews of Infectious Diseases 11 (1989), br. 5: 808-826.

Zaključci Hrvatskog sabora, svezak II (1693. - 1713.), priredili Josip Buturac, Mirko Stanisavljević, Ranko Sučić, Vesna Šojat i Bartol Zmajić. Zagreb: Državni arhiv NR Hrvatske u Zagrebu, 1958. 


\section{Plague Epidemics in Banal Croatia and Slavonia at the End of the 17th and the Beginning of the 18th Century: The Beginnings of Organizing the Public Health System}

\section{Summary}

The plague epidemics that ravaged the Habsburg Monarchy from 1677 to 1716 strongly influenced the development of health institutions and the organization of a public health system. Primarily, there was a need to employ a larger number of educated medical doctors and to establish institutions that would deal with health and epidemiological issues, especially during the epidemics. In 1710, Emperor Joseph I established the Court Sanitary Commission (Sanitäts-Hofkommission), which would soon become the central public health institution in the Habsburg Monarchy. Research of historical documents has shown that two other institutions were especially important for the Croatian-Slavonian lands during the epidemic of 1708-1716: the Court War Council in Vienna, and from 1710 the Hauptdeputation in Contagionssachen in Graz. It is evident from the mentioned documents that the Deputation, as the main (Haupt-) Inner Austrian anti-epidemic institution, also coordinated the anti-epidemic activities in Banal Croatia and the Varaždin Generalate. The plague epidemic in the Habsburg Monarchy from 1708 to 1716 is very important in this sense, because the experience and structure of the anti-epidemic system built at that time were the basis for the establishment of a later permanent system of Sanitary Commissions and Sanitary Cordon, which began in the 1730s and was fully formed with the enactment of the General Health Act (Generale Normativum in Re Sanitatis) in 1770. These experiences proved to be especially useful for Banal Croatia, which was not affected by the plague epidemic of 1708-1716 due to the anti-epidemic measures.

Keywords: plague, epidemics, public health, Croatia, Slavonia, 17th and 18th centuries

Robert Skenderović, Croatian Institute of History, Department for the History of Slavonia, Srijem and Baranja, Ante Starčevića 8, 35000 Slavonski Brod, Croatia, E-mail: rskender@isp.hr 